\title{
Effects of sodium diacetate on the fermentation profile, chemical composition and aerobic stability of alfalfa silage
}

\author{
XianJun Yuan', AiYou Wen ${ }^{1,2}$, Seare T. Desta ${ }^{1}$, Jian Wang ${ }^{1}$, and Tao Shao ${ }^{1, *}$
}

* Corresponding Author: Tao Shao Tel: +86-025-84396130, Fax: +86-025-84396130,

E-mail: shaotaola@163.com

'Institute of Ensiling and Processing of Grass, Nanjing Agricultural University, Nanjing 210095, China

${ }_{2}^{2}$ College of Animal Science, Anhui Science and Technology University, Fengyang 233100, China

Submitted Oct 9, 2016; Revised Nov 16, 2016; Accepted Dec 17, 2016
Objective: The objective of this study was to evaluate the effect of sodium diacetate (SDA) on fermentation profile, chemical composition and aerobic stability of alfalfa (Medicago sativa L.) silage.

Methods: Fresh alfalfa was ensiled with various concentrations of $\operatorname{SDA}(0,3,5,7$, and $9 \mathrm{~g} / \mathrm{kg}$ of fresh forage). After 60 days of the ensiling, the samples were collected to examine the fermentative quality, chemical composition and aerobic stability.

Results: The application of SDA significantly $(\mathrm{p}<0.05)$ decreased silage $\mathrm{pH}$ with the lowest value in silage with $7 \mathrm{~g} / \mathrm{kg}$ of SDA. The proliferations of enterobacteria, yeasts, molds and clostridia were inhibited by SDA, resulted in lower ethanol, propionic and butyric acid concentrations and dry matter loss in SDA treated silages than control. The increasing SDA linearly decreased free amino acid $\mathrm{N}(\mathrm{p}<0.001)$, ammonia $\mathrm{N}(\mathrm{p}=0.018)$ and non-protein $\mathrm{N}(\mathrm{p}<0.001)$, while linearly increased water soluble carbohydrate $(\mathrm{p}<0.001)$ and peptide $\mathrm{N}(\mathrm{p}<0.001)$. It is speculated that SDA accelerated the shift from homofermentative to heterofermentative lactic acid bacteria during the silage fermentation, indicated by lower lactic acid production in SDA-9 than SDA-7 silages after 60 days of ensiling. Alfalfa silages treated with SDA at $7 \mathrm{~g} / \mathrm{kg}$ had highest Flieg's point and remained stable more than $9 \mathrm{~d}$ during aerobic exposure under humid and hot conditions in southern China.

Conclusion: SDA may be used as an additive for alfalfa silages at a level of $7 \mathrm{~g} / \mathrm{kg}$.

Keywords: Alfalfa; Fermentation Quality; Sodium Diacetate; Silage

\section{INTRODUCTION}

Alfalfa (Medicago sativa) is considered one of the best forage crops for feeding ruminant animals because of its high nutritional value, and has been widely cultivated in southern China, regions characterized by hot and humid weather during the long summer. Thus, ensiling is the preferred method for preservation of alfalfa in these regions. However, alfalfa is difficult to preserve as silage due to its relatively low concentration of water soluble carbohydrate (WSC) and high buffering capacity [1].

The direct acidification of silages through organic acid leads to immediate drop in $\mathrm{pH}$ and inhibition on growth of undesirable bacteria, which result in the reduction of nutrients loss [2]. However, organic acids are difficult to handle because of their pungent and offensive odor, safer salts of organic acid have been proposed as alternative silage additives [3]. Sodium diacetate (SDA), an acetate derivative and food preservative, consists of sodium acetate and acetic acid, which have been proven effective substances for inhibition of the growth of enterobacteria and yeast [4]. SDA is an effective microbial inhibitor and has been used as an antibacterial agent to prolong the shelf life of silages [5].

Wilting alfalfa to sufficient dry matter (DM) content before ensiling is difficult due to wet weather, while fresh alfalfa silage is more prone to clostridial spoilage due to the high moisture 
[6]. Since exploiting novel silage additives for low DM silages under wet and hot condition is necessary, it was hypothesized that SDA could be used as silage additives based on its antimicrobial characteristics. Therefore, the effects of various concentrations of SDA on fermentation and microbial characteristics, nitrogenous components and aerobic stability of fresh alfalfa silage were evaluated in this study.

\section{MATERIALS AND METHODS}

\section{Ensiling procedure}

Alfalfa was grown in experimental plots at Anhui Science and Technology University $\left(32^{\circ} 52^{\prime}\right.$ latitude N, $117^{\circ} 33^{\prime}$ longitude E, FengYang, Anhui, China). Second cut alfalfa was harvested at early flowering stage and chopped into approximately $1.5 \mathrm{~cm}$ particle size, and then ensiled with SDA ( $\geq 98 \%$, Hubei Ju Sheng Technology Co., Ltd., Hubei, China) at $0,3,5,7$, or $9 \mathrm{~g} / \mathrm{kg}$ of fresh forage (defined as control, SDA-3, SDA-5, SDA-7, and SDA-9, respectively). About $780 \mathrm{~g}$ treated alfalfa was packed into plastic laboratory silos (1-L capacity, $9.5 \mathrm{~cm}$ diameter $\times 18.7 \mathrm{~cm}$ height, Lantian biological experimental instrument Co., Ltd., Jiangsu, China), followed by sealing with two screw tops (internal and external). Twelve replicated silos per treatment were made and stored at ambient temperature $\left(32^{\circ} \mathrm{C}\right.$ to $\left.37^{\circ} \mathrm{C}\right)$. All silos were opened on $60 \mathrm{~d}$ after ensiling, 6 silos for each treatment were sampled for fermentation quality analysis. Another 6 silos per treatment were used for aerobic stability test: alfalfa silages from each silo were mixed thoroughly and placed into separate new sterile plastic bigger silo (5 L capacity, $17.3 \mathrm{~cm}$ diameter $\times 26.5$ $\mathrm{cm}$ height, Lantian biological experimental instrument Co., Ltd., China) without compaction, which was kept uncovered and stored for 9 days at ambient temperature $\left(29^{\circ} \mathrm{C}\right.$ to $\left.33^{\circ} \mathrm{C}\right)$. The room and silage temperatures were recorded two-hourly by a glass thermometer. Aerobic stability was defined as the number of hours that the silage remained stable before its temperature increased by $2^{\circ} \mathrm{C}$ above ambient temperature.

\section{Chemical analysis}

At sampling, the entire content of each silo was emptied and placed in an ethanol disinfected plastic container to mix uniformity. A sub-sample of silages was diluted with 1:2 (w/v) distilled water and stored in the refrigerator at $4^{\circ} \mathrm{C}$ for $24 \mathrm{~h}$, followed by filtration through two layers of cheesecloth. The extract $\mathrm{pH}$ was measured immediately with a pH meter (HANNA pH 211, Hanna Instruments Italia Srl, Villafranca, Padovana, Italy). The extract was centrifuged for $10 \mathrm{~min}$ at $10,000 \times \mathrm{g}$, and the supernatant was reserved for organic acid (including lactic, acetic, propionic, and butyric acid) and ethanol analyses, which were carried out by Agilent 1260 HPLC system (Agilent Technologies, Inc., Waldbronn, Germany) equipped with a refractive index detector (column: Carbomix H-NP5, Sepax Technologies, Inc., Newark, DE, USA; eluent: $2.5 \mathrm{mM} \mathrm{H}_{2} \mathrm{SO}_{4}, 0.5 \mathrm{~mL} / \mathrm{min}$; temperature: $55^{\circ} \mathrm{C}$ ).
A $10 \mathrm{~mL}(250 \mathrm{~g} / \mathrm{L}, \mathrm{w} / \mathrm{v})$ trichloroacetic acid (TCA) was added to $40 \mathrm{~mL}$ of the extract, and the solution was held at $4^{\circ} \mathrm{C}$ overnight to precipitate the protein. The solution was then centrifuged at $18,000 \times \mathrm{g}$ for $15 \mathrm{~min}$ and the supernatant was analyzed for ammonia $\mathrm{N}$ and free amino acid $\mathrm{N}$ (FAA-N) [7]. An aliquot of 10 $\mathrm{mL}$ TCA supernatant was taken for determination of non-protein $\mathrm{N}(\mathrm{NPN})$ concentration by Kjeldahl nitrogen analyzer as described by Licitra et al [8]. Peptide $\mathrm{N}$ concentration was determined by the increase of FAA-N in the TCA supernatant after digesting with $6 \mathrm{~mol} / \mathrm{L}$ hydrochloric acid for $21 \mathrm{~h}$ at $105^{\circ} \mathrm{C}$ [9].

One subsample $(100 \mathrm{~g})$ of fresh materials or silages was freezedried to determine DM content. The lyophilized sample was ground to pass a 1-mm screen with a mill (FW100, Taisite Instrument Co., Ltd., Tianjin, China). The DM loss was calculated using DM content and silo weight measured before and after ensiling. The content of WSC was analyzed by colorimetry after reaction with anthrone reagent [10]. Total nitrogen (TN) was determined by Kjeldahl nitrogen analyzer (Kjeltec 8400 Analyzer; FOSS Analytical AB, Höganäs, Sweden), crude protein (CP) content was calculated by multiplying TN by 6.25 . The buffering capacity was determined according the procedure described by Playne and McDonald [11].

\section{Microbial populations}

The microorganism numbers in the fresh materials and silages were determined by the plate count method. Samples (10 g) were homogenized in $90 \mathrm{~mL}$ of sterilized water for $1 \mathrm{~min}$, and the liquid from the blended samples were serially diluted (10-fold). The lactic acid bacteria (LAB) were counted on deMan, Rogosa and Sharp (MRS) agar medium (Shanghai Bio-way Technology Co., Ltd., Shanghai, China) after incubation in an anaerobic incubator (YQX-II, CIMO Medical Instrument Manufacturing Co., Ltd., Shanghai, Shanghai, China) at $37^{\circ} \mathrm{C}$ for 3 days. Yeasts and molds were counted on potato dextrose agar (Shanghai Bioway technology Co., Ltd., China) acidified with sterilized tartaric acid solution to $\mathrm{pH} 3.5$, which were incubated at $37^{\circ} \mathrm{C}$ for 3 days. Enterobacteria were counted on Violet Red Bile Agar (Shanghai Bio-way Technology Co., Ltd., China) at $37^{\circ} \mathrm{C}$ for 3 days. Clostridia were counted on tryptose sulfite cycloserine agar (Shanghai Bio-way Technology Co., Ltd., China) after incubation in an anaerobic incubator at $35^{\circ} \mathrm{C}$ for 3 to $5 \mathrm{~d}$. All microbial data were transformed to $\log 10$ and presented on a wet weight basis.

\section{Statistical analysis}

The quality of all alfalfa silages was assessed by the index of Flieg's point which was calculated by means of the $\mathrm{pH}$ values and $\mathrm{DM}$ of the silages, measured at the end of ensiling with the following equation [12]:

Flieg's point $=220+(2 \times \% \mathrm{DM}-15)-40 \times \mathrm{pH}$

The data were analyzed as a completely randomized design 
using the general linear model (GLM) procedure of SAS 9.3 (SAS Inst. Inc., Cary, NC, USA) with treatments as fixed effect. The model used to analyze individual treatment effects was: $Y_{i j}=\mu+$ $\mathrm{T}_{\mathrm{i}}+\mathrm{E}_{\mathrm{ij}}$; where $\mu$ = general mean; $\mathrm{T}_{\mathrm{i}}=$ effect of treatment (additive); and $\mathrm{E}_{\mathrm{ij}}=$ experimental error. Orthogonal polynomial contrasts were used to determine linear and quadratic responses to dose of SDA, while Tukey's multiple comparisons was used to compare differences in $\mathrm{pH}$, Flieg's point and aerobic stability among all treatments. An alpha level of $\mathrm{p}<0.05$ was deemed significant.

\section{RESULTS}

Chemical composition and microbial populations of fresh alfalfa prior to ensiling are listed in Table 1. The alfalfa was harvested at the early bloom stage and had a DM of $253 \mathrm{~g} / \mathrm{kg}$ fresh weight (FW) before ensiling. The WSC and CP contents in alfalfa were 51.6 and $216 \mathrm{~g} / \mathrm{kg} \mathrm{DM}$, respectively. The buffering capacity of fresh alfalfa was $339 \mathrm{mEq} / \mathrm{kg}$ DM. The initial populations of $\mathrm{LAB}$, yeast, molds, enterobacteria and clostridia in fresh alfalfa were $5.82,3.61,3.99,6.98$, and $2.52 \log _{10}$ colony-forming unit (cfu)/g, respectively.

As shown in Table 2 , the increasing SDA linearly $(\mathrm{p}<0.01)$ decreased propionic acid $(\mathrm{PA})(\mathrm{p}<0.001)$, butyric acid $(\mathrm{BA})(\mathrm{p}<0.001)$,
Table 1. Chemical composition and microbial populations of alfalfa before ensiling

\begin{tabular}{lc}
\hline Items & Value \\
\hline Dry matter (g/kg FW) & 253 \\
Lactic acid bacteria $\left(\log _{10} \mathrm{cfu} / \mathrm{g} \mathrm{FW}\right)$ & 5.82 \\
Yeast $\left(\log _{10} \mathrm{cfu} / \mathrm{g} \mathrm{FW}\right)$ & 3.61 \\
Molds $\left(\log _{10} \mathrm{cfu} / \mathrm{g} \mathrm{FW}\right)$ & 3.99 \\
Enterobacteria $\left(\log _{10} \mathrm{cfu} / \mathrm{g} \mathrm{FW}\right)$ & 6.98 \\
Clostridia $\left(\log _{10} \mathrm{cfu} / \mathrm{g} \mathrm{FW}\right)$ & 2.52 \\
Crude protein $(\mathrm{g} / \mathrm{kg} \mathrm{DM})$ & 216 \\
Water soluble carbohydrate $(\mathrm{g} / \mathrm{kg} \mathrm{DM})$ & 51.6 \\
Buffering capacity $(\mathrm{mEg} / \mathrm{kg}$ DM) & 339 \\
\hline
\end{tabular}

FW, fresh weight; DM, dry matter.

and ethanol $(\mathrm{p}<0.001)$, and a similar response $(\mathrm{p}<0.001)$ also occurred in the populations of enterobacteria, yeasts, molds and clostridia. The concentration of acetic acid (AA) linearly $(\mathrm{p}<0.01)$ increased as the proportion of SDA increased. A quadratic response of lactic acid (LA) $(\mathrm{p}=0.043), \mathrm{PA}(\mathrm{p}<0.001)$, molds ( $\mathrm{p}<$ $0.001)$, and clostridia $(\mathrm{p}<0.001)$ to increasing proportion of SDA was observed.

The chemical composition and nitrogen fractions of alfalfa silages after 60 days of ensiling are presented in Table 3. The increasing SDA linearly decreased DM loss ( $\mathrm{p}<0.001)$, FAA-N

Table 2. Fermentation characteristics and microbial populations of alfalfa ensiled with different levels of sodium diacetate

\begin{tabular}{|c|c|c|c|c|c|c|c|c|}
\hline \multirow{2}{*}{ Items } & \multicolumn{5}{|c|}{ Levels of sodium diacetate $(\mathrm{g} / \mathrm{kg})$} & \multirow{2}{*}{ SEM } & \multicolumn{2}{|c|}{ p-value $e^{1)}$} \\
\hline & 0 & 3 & 5 & 7 & 9 & & $\mathbf{L}$ & Q \\
\hline Lactic acid (g/kg DM) & 15.9 & 25.4 & 33.5 & 37.9 & 28.3 & 1.25 & 0.003 & 0.043 \\
\hline Acetic acid (g/kg DM) & 17.2 & 21.7 & 25.6 & 33.7 & 40.2 & 2.17 & $<0.001$ & 0.081 \\
\hline Propionic acid (g/kg DM) & 4.92 & 2.75 & 1.56 & 0.78 & 0.62 & 0.365 & $<0.001$ & $<0.001$ \\
\hline Butyric acid (g/kg DM) & 2.65 & 2.93 & 1.11 & 0.79 & 0.49 & 0.246 & $<0.001$ & 0.345 \\
\hline Ethanol (g/kg DM) & 6.03 & 5.06 & 4.07 & 3.99 & 3.65 & 0.235 & $<0.001$ & 0.082 \\
\hline Lactic acid bacteria ( $\log _{10}$ cfu/g FW) & 7.10 & 7.66 & 7.36 & 7.39 & 7.36 & 0.074 & 0.625 & 0.163 \\
\hline Enterobacteria $\left(\log _{10} \mathrm{cfu} / \mathrm{g} \mathrm{FW}\right)$ & 5.11 & 3.72 & 3.79 & 3.51 & 3.22 & 0.096 & 0.002 & 0.814 \\
\hline Yeasts ( $\log _{10}$ cfu/g FW) & 5.93 & 4.79 & 3.89 & 3.15 & 2.99 & 0.101 & $<0.001$ & 0.047 \\
\hline Molds ( $\log _{10}$ cfu/g FW) & 5.13 & 2.09 & 2.23 & 2.02 & 1.83 & 0.293 & $<0.001$ & $<0.001$ \\
\hline Clostridia $\left(\log ^{10} \mathrm{cfu} / \mathrm{g} \mathrm{FW}\right)$ & 1.94 & 1.09 & 0.62 & 1.08 & 0.94 & 0.107 & $<0.001$ & $<0.001$ \\
\hline
\end{tabular}

SEM, standard error of the mean; DM, dry matter; FW, fresh weight.

1) $L$ and $Q$ represent linear and quadratic effect of sodium diacetate.

Table 3. Chemical composition and nitrogen fractions of alfalfa ensiled with different levels of sodium diacetate

\begin{tabular}{|c|c|c|c|c|c|c|c|c|}
\hline \multirow{2}{*}{ Items } & \multicolumn{5}{|c|}{ Levels of sodium diacetate $(\mathrm{g} / \mathrm{kg})$} & \multirow{2}{*}{ SEM } & \multicolumn{2}{|c|}{ p-value $^{1)}$} \\
\hline & 0 & 3 & 5 & 7 & 9 & & $\mathbf{L}$ & Q \\
\hline Dry matter (g/kg FW) & 233 & 231 & 228 & 230 & 232 & 2.45 & 0.052 & 0.732 \\
\hline Dry matter loss (\%) & 11.9 & 11.2 & 10.5 & 9.19 & 8.72 & 0.306 & $<0.001$ & 0.121 \\
\hline Water soluble carbohydrate (g/kg DM) & 14.0 & 14.5 & 15.5 & 16.8 & 18.9 & 0.53 & $<0.001$ & 0.010 \\
\hline Crude protein (g/kg DM) & 212 & 207 & 214 & 210 & 206 & 2.18 & 0.624 & 0.660 \\
\hline Free amino acid nitrogen (g/kg TN) & 287 & 235 & 235 & 233 & 218 & 5.82 & $<0.001$ & 0.001 \\
\hline Ammonia nitrogen ( $\mathrm{g} / \mathrm{kg}$ TN) & 119.6 & 98.6 & 82.8 & 64.9 & 68.9 & 4.00 & 0.018 & 0.996 \\
\hline Peptide nitrogen (g/kg TN) & 188 & 216 & 219 & 215 & 213 & 3.01 & $<0.001$ & $<0.001$ \\
\hline Non-protein nitrogen ( $/ \mathrm{kg}$ TN) & 582 & 543 & 528 & 503 & 496 & 8.04 & $<0.001$ & 0.006 \\
\hline
\end{tabular}

SEM, standard error of the mean; FW, fresh weight; DM, dry matter; TN, total nitrogen.

1) $L$ and $Q$ represent linear and quadratic effect of sodium diacetate. 
$(\mathrm{p}<0.001)$, ammonia $\mathrm{N}(\mathrm{p}=0.018)$ and $\mathrm{NPN}(\mathrm{p}<0.001)$, while linearly increased WSC $(\mathrm{p}<0.001)$ and peptide $\mathrm{N}(\mathrm{p}<0.001)$. A quadratic response of WSC $(\mathrm{p}=0.01)$, FAA-N $(\mathrm{p}=0.001)$, peptide $\mathrm{N}(\mathrm{p}<0.001)$, and NPN $(\mathrm{p}=0.006)$ to increasing SDA was observed.

The silages treated with $7 \mathrm{~g} / \mathrm{kg}$ SDA had the lowest $\mathrm{pH}$, followed by the SDA- 5 and SDA- 9 , which in turn were significantly lower $(\mathrm{p}<0.05)$ than control and SDA-3 silages (Figure 1). According to the Flieg's index for silage quality, all silage did not reach high quality (81-100), SDA-7 showed the highest Flieg's point (78.3), which was significantly higher $(p<0.05)$ than that of control and SDA-3 silages (Figure 2).

The aerobic stability of alfalfa silages, represented as hours that the temperature of the silage remained stable before increasing more than $2^{\circ} \mathrm{C}$ above ambient temperature, is shown in Figure 3. The increasing SDA prolonged the aerobic stability of alfalfa silage with aerobic stable for $156,178,198,>216$, and $>216 \mathrm{~h}$ in silages treated with $0,3,5,7$, and $9 \mathrm{~g} / \mathrm{kg}$ FW SDA, respectively.

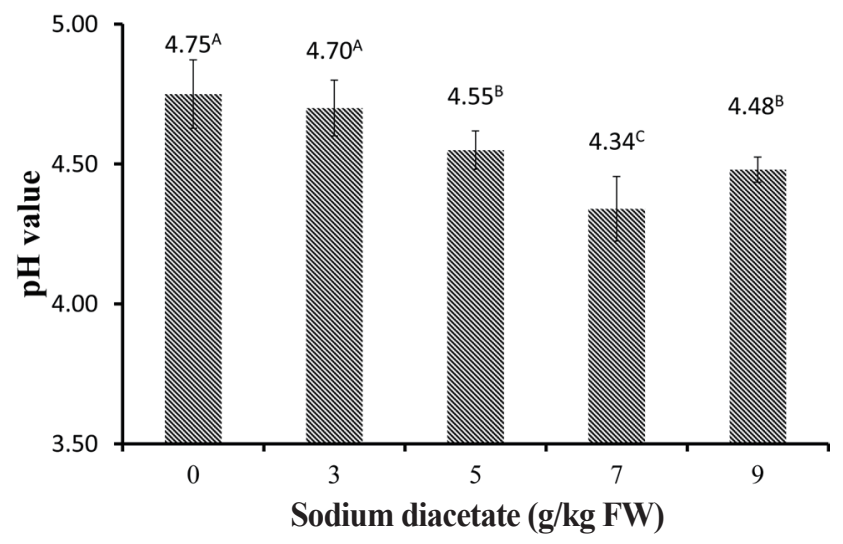

Figure 1. The $\mathrm{pH}$ value of alfalfa silages treated with $0,3,5,7$, and $9 \mathrm{~g} / \mathrm{kg} \mathrm{FW}$ sodium diacetate ensiled for 60 days. Vertical bars are the standard errors of the means, bars with unlike letters differ $(p<0.05, n=5)$. FW, fresh weight.

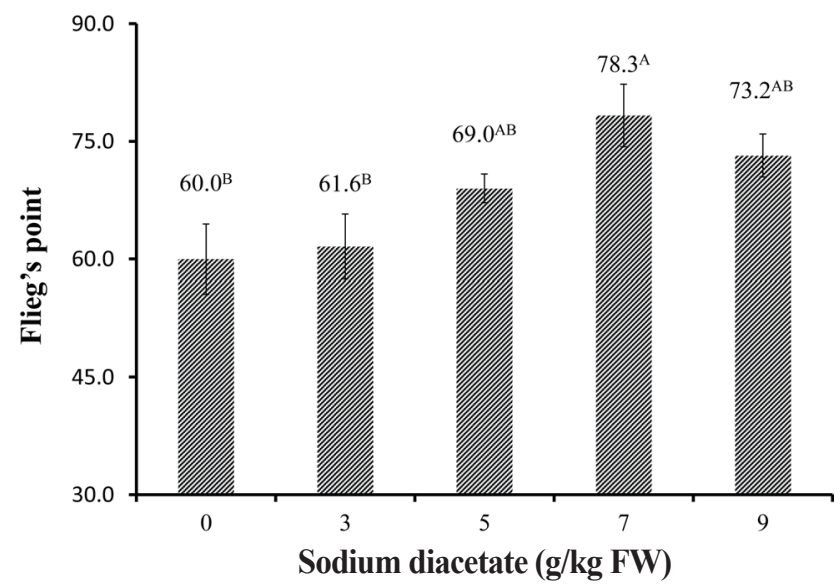

Figure 2. Flieg's point of alfalfa silages treated with $0,3,5,7$, and $9 \mathrm{~g} / \mathrm{kg} \mathrm{FW}$ sodium diacetate ensiled for 60 days. Vertical bars are the standard errors of the means, bars with unlike letters differ $(p<0.05, n=5)$. FW, fresh weight.

\section{DISCUSSION}

In order to model farmers' systems of practices in humid and rainy southern China, where it is difficult to achieve sufficient DM content in cut crop by wilting, fresh alfalfa was ensiled on the day of harvesting with the DM concentration of $253 \mathrm{~g} / \mathrm{kg}$. The DM content of a crop at ensiling affects the rate and extent of the resulting fermentation, and the low DM and WSC content associated with high buffering capacity increase the chance of clostridial fermentation and subsequent poor acceptance of the silage by the animals [13]. Fresh alfalfa is critical for a successful fermentation due to its low DM and WSC concentration (51.6 $\mathrm{g} / \mathrm{kg}$ ) and high buffering capacity ( $339 \mathrm{mEq} / \mathrm{kg} \mathrm{DM})$. The epiphytic LAB populations $\left(5.82 \log _{10} \mathrm{cfu} / \mathrm{g}\right.$ ) is adequate, considering the recommendation of $5 \log _{10} \mathrm{cfu} / \mathrm{g}$ as a minimum required to ensure good fermentation during the ensiling [1].

The high $\mathrm{pH}$ (4.75) in control silage reflected an average fermentative quality for untreated alfalfa, which is considered a difficult crop to ensile due to low WSC content and relatively high buffering capacity [14]. The significantly lower $\mathrm{pH}$ in silages treated with SDA above $5 \mathrm{~g} / \mathrm{kg}$ probably were attributed to acidification functions of SDA, which is a readily available source of both acetic acid and sodium acetate. Woolford [15] found that the acidic properties of the organic acids decreased with the increase of chain length, indicating the intensive acidification function of acetic acid. The variations in concentrations of lactic and acetic acid also contributed to the differences in silage $\mathrm{pH}$ among treatments. There was a quadratic response of $\mathrm{pH}$ to increasing SDA with the lowest $\mathrm{pH}$ in SDA-7, which was consistent with a lower LA concentration in SDA-9 than SDA-7. Dellaglio and Torriani [16] reported that fermentation was initiated by homofermentative $\mathrm{LAB}$ which dominated until day 60 , after which there was a gradual decline with a concomitant increase in heterofermentative species due to their greater tolerance to acetic acid. In the present study, the acetic acid ionization from

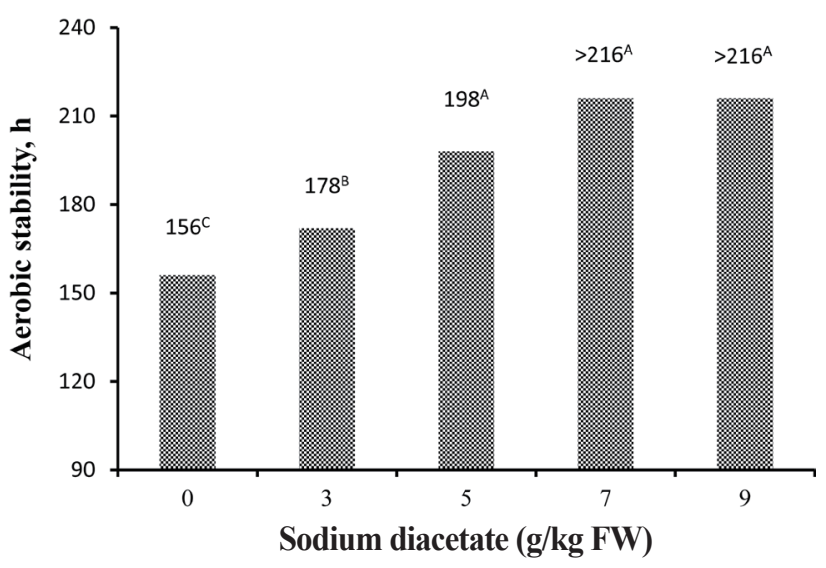

Figure 3. Aerobic stability of alfalfa silages treated with $0,3,5,7$, and $9 \mathrm{~g} / \mathrm{kg} \mathrm{FW}$ sodium diacetate ensiled for 60 days. Bars with unlike letters differ $(p<0.05, n=5)$. FW, fresh weight. 
SDA probably accelerated the shift from homofermentative to heterofermentative LAB during the silage fermentation, resulted in lower LA and higher acetic acid concentrations in SDA-9 than SDA-7 silages after 60 days of ensiling.

The higher LA concentration in silages treated with SDA than control might be due to the antimicrobial attribute of acetic acid ionization from SDA. Acetic acid is one of the most effective substances for inhibition of undesirable microorganisms. Danner et al [4] assumed that the antimicrobial activity of acetate was caused by the lipophilic, undissociated acid molecules which could penetrate the bacterial plasma membrane and disturb the microbial metabolism. The antimicrobial effect of an organic acid depends upon its $\mathrm{pKa}$ and the $\mathrm{pH}$ of the medium, acetic acid has a pKa of 4.75 , thus the higher antimicrobial activity of acetic acid occurred in SDA-5, SDA-7, and SDA-9 silages, since a greater proportion of the acetate was not dissociated in these silages with lower surrounding $\mathrm{pH}$ values. These antimicrobial activities were also reflected in lower populations of enterobacteria, yeast, molds and clostridia in alfalfa silages treated with SDA than control after 60 days of ensiling.

The significantly higher acetic acid concentrations were present in SDA treated silages, which were consistent with the addition of SDA before ensiling. This confirmed the above hypothesis that the antimicrobial activity and acidification in SDA treated silages was brought by the acetic acid resulting from ionization of SDA.

The butyric acid concentrations in control silages was higher than the acceptable level $(2.0 \mathrm{~g} / \mathrm{kg} \mathrm{DM})$ for well-preserved silages [17], while that in SDA-7 and SDA-9 silage was below $1.0 \mathrm{~g} / \mathrm{kg}$. The lower butyric acid concentration in silages treated with SDA than control suggested that clostridia growth was inhibited during the ensiling [6]. Clostridial fermentation occurs particularly when ensiled crop is low in WSC and DM contents at high temperatures, the dramatic decrease in silage $\mathrm{pH}$ can hinder the growth of clostridia [3]. The addition of SDA showed acidification and antimicrobial activity and decreased clostridia numbers in alfalfa silages. The restriction of clostridial fermentation by chemicals is also typically reflected as a lower ammonia $\mathrm{N}$, which is another metabolic product of clostridia [3]. The ammonia $\mathrm{N}$ in SDA-7 and SDA- 9 silage was only $54 \%$ and $58 \%$ of that in control (119.6 $\mathrm{g} / \mathrm{kg} \mathrm{TN}$ ), which had higher ammonia $\mathrm{N}$ than maximum acceptable value (100 g/kg TN) for well-preserved silages [18].

An efficient silage system for feed production should ensure low level of DM and nutrient losses. Muck [19] summarized 3 processes as being responsible for excessive DM and energy losses, included plant respiration, aerobic microorganism growth, and clostridia growth. In the present experiment, the application of SDA probably depressed the aerobic microorganism and clostridia growth, since acetic acid is one of the most effective substances for inhibition on undesirable microorganisms [15]. The lower DM losses in the SDA treated silages were consistent to the lower undesirable bacteria (including enterobacteria, yeasts, molds and clostridia) populations than the control. Goeser et al [20] summarized a wide range of published reports through metaanalysis and outlined that additives (including formic or propionic acid, sodium benzoate, potassium sorbate, or sodium nitrite) could act on inhibiting undesirable microbial growth and DM losses.

Tabacco et al [21] found that DM losses were related to the depletion of the digestible carbohydrate and organic acid fractions. In the present study, SDA inhibited the activity of undesirable microorganism, which metabolized soluble carbohydrate into carbon dioxide and other metabolic products, resulted in a linear increase of WSC with increasing rate of SDA. In agreement with the previous study by Da Silva et al [22], who found that chemicalbased additives with antifungal properties significantly increased WSC concentrations compared to untreated corn silage after 21 days of ensiling.

It is well known that extensive proteolysis occurs during the ensiling of alfalfa and that plant proteins are degraded to NPN, owing to the action of both plant and microbial proteases. The main consequences of these processes are the low utilization efficiency of silage $\mathrm{N}$ by ruminants and reduction of the nutritional value and intake of the silages [23]. In the present study, the addition of SDA lowered the NPN concentration, which was mainly comprised of lower FAA-N and ammonia $\mathrm{N}$ in the SDA treated silages than in control silage. The FAAs are primary intermediate products of proteolysis by plant enzymes during the initial stage of ensiling and represent a pool of amino acids degraded by plant protease and amino acids being metabolized by microorganisms [24]. In the present study, SDA treated silages had lower ammonia $\mathrm{N}$ concentrations due to their inhibition effect on undesirable bacteria as mention above, suggested less FAAs were degraded to ammonia. Thus, the lower FAA-N concentrations in SDA treated silages were mainly attributed to weaker proteolysis by plant enzymes during the initial stage of ensiling. The inactivation of plant proteases might be due to the acidification function of acetic acid ionization from SDA, as reported by Jones et al [25], who found that $67 \%$ of plant protease activities were lost after $24 \mathrm{~h}$ at $\mathrm{pHs} 4$ and 5.

Flieg's point is a method for evaluating the quality of silages through the DM content and $\mathrm{pH}$ in the silages: silage was considered to be very bad when it had score of $<20$; to be bad with a score between 21 and 40; to be medium with a score between 41 and 60; to be good with a score between 61 and 80 and to be very good when it had score between 81 and 100 [12]. In the present study, control silage had a Flieg's point of 56.1, characterized by a typical medium fermentation quality of legume; the addition to SDA increased the Flieg's point with the highest value in SDA-7 (78.3). It is speculated that the addition of 3\% or $5 \%$ SDA was not enough to inhibit the growth of undesirable bacteria, while high level application $(9 \mathrm{~g} / \mathrm{kg} \mathrm{FW})$ not only inhibited the undesirable bacteria but also had some inhibition effect on LA fermentation.

Although legume silages have been reported to be aerobically 
relatively stable [26], environmental conditions encountered in the tropics can enhance growth of spoilage microorganisms and accelerate the aerobic spoilage during the feed-out. The proliferations of yeasts, aerobic bacteria and molds cause the increase in temperature and $\mathrm{pH}$, result in the nutrients loss and increase the risk of proliferation of potential pathogenic or undesirable microorganisms, thus affecting the performance of animals fed the silage [27]. Kung Jr and Ranjit [28] defined the aerobic stability as the number of hours that the silage remained stable before increasing more than $2^{\circ} \mathrm{C}$ above the ambient temperature. In the present study, the poorer aerobic stability (stable only for $156 \mathrm{~h}$ ) in untreated alfalfa silages was consistent with the higher yeasts numbers (5.93). Wilkinson and Davies [29] reported that yeasts were primary responsible for the onset of aerobic spoilage of silage, and yeasts counts in excess of $5 \log _{10} \mathrm{cfu} / \mathrm{g}$ are likely to be associated with aerobic deterioration. The addition of SDA delayed the rise of temperature in alfalfa silages with longest stable intervals in SDA-7 and SDA-9 silages (>216 h), which were consistent with the lower yeast numbers (below $5 \log _{10} \mathrm{cfu} / \mathrm{g}$ ). Based on the aerobic spoilage definition above, application of SDA above 7 $\mathrm{g} / \mathrm{kg} \mathrm{FW}$ ensured the alfalfa silage retained stability more than $9 \mathrm{~d}$ during the feed-out period under humid and rainy conditions in southern China.

\section{CONCLUSION}

The application of SDA decreased silage $\mathrm{pH}$ with the lowest $\mathrm{pH}$ in SDA-7. The antimicrobial activity of SDA was reflected in the lower populations of enterobacteria, yeast, molds and clostridia, resulted in the lower propionic, butyric acid, ethanol, ammonia $\mathrm{N}$ and DM loss in silages treated with SDA than control. Alfalfa silages treated with SDA at $7 \mathrm{~g} / \mathrm{kg}$ FW had highest Flieg's point and retained stability more than $9 \mathrm{~d}$ during the feed-out period under humid and hot conditions in southern China.

\section{CONFLICT OF INTEREST}

We certify that there is no conflict of interest with any financial organization regarding the material discussed in the manuscript.

\section{ACKNOWLEDGMENTS}

This work was partially supported by National Natural Science Foundation of China (31402135), Natural Science Foundation of Jiangsu Province of China (BK20140717) and Fundamental Research Funds for the Central Universities (KJQN201555).

\section{REFERENCES}

1.Silva VP, Pereira OG, Leandro ES, et al. Effects of lactic acid bacteria with bacteriocinogenic potential on the fermentation profile and chemical composition of alfalfa silage in tropical conditions. J Dairy
Sci 2016;99:1895-902.

2.Cazzato E, Laudadio V, Corleto A, Tufarelli V. Effects of harvest date, wilting and inoculation on yield and forage quality of ensiling safflower (Carthamus tinctorius L.) biomass. J Sci Food Agric 2011;91:2298302.

3.Oladosu Y, Rafii MY, Abdullah N, et al. Fermentation quality and additives: a case of rice straw silage. Biomed Res Int 2016;ID:7985167.

4.Danner H, Holzer M, Mayrhuber E, Braun R. Acetic acid increases stability of silage under aerobic conditions. Appl Environ Microb 2003;69:562-7.

5.Shockey W, Heinrichs A, Weiss W, Conrad H. Evaluation of sodium diacetate-treated alfalfa silage for lactating dairy cows. J Prod Agric 1990;3:381-5.

6.Knicky M, Sporndly R. Sodium benzoate, potassium sorbate and sodium nitrite as silage additives. J Sci Food Agric 2009;89:2659-67.

7.Broderick GA, Kang JH. Automated simultaneous determination of ammonia and total amino acids in ruminal fluid and in vitro media. J Dairy Sci 1980;63:64-75.

8.Licitra G, Hernandez TM, Van Soest PJ. Standardization of procedures for nitrogen fractionation of ruminant feeds. Anim Feed Sci Technol 1996;57:347-58.

9.Muck R. Dry matter level effects on alfalfa silage quality. I. Nitrogen transformations. Trans ASAE 1987;30:7-14.

10. Thomas TA. An automated procedure for the determination of soluble carbohydrates in herbage. J Sci Food Agric 1977;28:639-42.

11. Playne MJ, McDonald P. The buffering constituents of herbage and of silage. J Sci Food Agric 1966;17:264-8.

12. Moselhy MA, Borba JP, Borba AES. Improving the nutritive value, in vitro digestibility and aerobic stability of Hedychium gardnerianum silage through application of additives at ensiling time. Anim Feed Sci Technol 2015;206:8-18.

13. Nkosi BD, Meeske R. Effects of ensiling totally mixed potato hash ration with or without a heterofermentative bacterial inoculant on silage fermentation, aerobic stability, growth performance and digestibility in lambs. Anim Feed Sci Technol 2010;161:38-48.

14. Denek N, Can A, Avci M, Aksu T, Durmaz H. The effect of molassesbased pre-fermented juice on the fermentation quality of first-cut lucerne silage. Grass Forage Sci 2011;66:243-50.

15. Woolford MK. Microbiological screening of the straight chain fatty acids (c1-c12) as potential silage additives. J Sci Food Agric 1975;26: 219-28.

16. Dellaglio F, Torriani S. DNA-DNA homology, physiological characteristics and distribution of lactic acid bacteria isolated from maize silage. J Appl Bacteriol 1986;60:83-92.

17. Castle ME, Watson JN. Silage and milk production: studies with molasses and formic acid as additives for grass silage. Grass Forage Sci 1985;40:85-92.

18. Yuan X, Yu C, Shimojo M, Shao T. Improvement of fermentation and nutritive quality of straw-grass silage by inclusion of wet hulless-barley distillers' grains in Tibet. Asian-Austral J Anim 2012;25:479-85.

19. Muck RE. Factors influencing silage quality and their implications for management. J Dairy Sci 1988;71:2992-3002. 
20. Goeser JP, Heuer CR, Crump PM. Forage fermentation product measures are related to dry matter loss through meta-analysis. Prof Anim Sci 2015;31:137-45.

21. Tabacco E, Righi F, Quarantelli A, Borreani G. Dry matter and nutritional losses during aerobic deterioration of corn and sorghum silages as influenced by different lactic acid bacteria inocula. J Dairy Sci 2011;94:1409-19.

22. Da Silva TC, Smith ML, Barnard AM, Kung L, Jr. The effect of a chemical additive on the fermentation and aerobic stability of high-moisture corn. J Dairy Sci 2015;98:8904-12.

23. Fijalkowska M, Pysera B, Lipinski K, Strusinska D. Changes of nitrogen compounds during ensiling of high protein herbages - a review. Ann Anim Sci 2015;15:289-305.

24. Guo X, Zhou H, Yu Z, Zhang Y. Changes in the distribution of nitrogen and plant enzymatic activity during ensilage of lucerne treated with different additives. Grass Forage Sci 2007;62:35-43.

25. Jones BA, Hatfield RD, Muck RE. Characterization of Proteolysis in alfalfa and red clover. Crop Sci 1995;35:537-41.

26. Ogunade IM, Kim DH, Jiang Y, et al. Control of Escherichia coli O157:H7 in contaminated alfalfa silage: Effects of silage additives. J Dairy Sci 2016;99:4427-36.

27. Nkosi BD, Meeske R, Langa T, et al. Effects of ensiling forage soybean (Glycine $\max (\mathrm{L}$.) Merr.) with or without bacterial inoculants on the fermentation characteristics, aerobic stability and nutrient digestion of the silage by Damara rams. Small Rumin Res 2016;134:90-6.

28. Kung Jr L, Ranjit NK. The effect of lactobacillus buchneri and other additives on the fermentation and aerobic stability of barley silage. J Dairy Sci 2001;84:1149-55.

29. Wilkinson JM, Davies DR. The aerobic stability of silage: key findings and recent developments. Grass Forage Sci 2013;68:1-19. 